\title{
Knowledge, Attitude and Practice of Health Care Workers in Sulaimani Health Facilities in Relation to Medical Waste Management
}

\author{
Sarko Masood Mohammed \\ Community Health Dept, \\ Technical College of Health, \\ Sulaimani Polytechnic University, \\ Sulaimani, Iraq \\ sarko.mohammed@spu.edu.iq
}

\author{
Nasih Othman \\ Kurdistan Institution for Strategic \\ Studies and Scientific Research, \\ Sulaimani, Iraq \\ nasih.othman@kissr.edu.krd
}

\author{
Ali Hattem Hussain \\ Community Health Dept, \\ Technical College of Health, \\ Sulaimani Polytechnic University, \\ Sulaimani, Iraq \\ ali.hussain@spu.edu.iq
}

\author{
Kamal Jalal Rashid \\ Anesthesiology Dept, \\ Technical College of Health, \\ Sulaimani Polytechnic University, \\ Sulaimani, Iraq \\ Kamal.rashid@spu.edu.iq
}

\begin{abstract}
Medical waste management is of crucial importance in health care facilities $(\mathrm{HCF})$. In the present study, we assessed the knowledge, attitude and practices of medical waste management in an $\mathrm{HCF}$ of Sulaimani city, Kurdistan Region of Iraq. Using a selfadministered questionnaire, we collected information on waste management practices from health care professionals $(\mathrm{HCP})$ in 14 public and private hospitals and 10 primary health care centers of the city. Based on answers, total knowledge score on a 10-point scale was established. A total of 406 HCPs (of those, 261 women), average age $37.3(S D \pm 9.4)$ years participated. Just $20.3 \%$ have been trained on medical waste management. The total knowledge score ranged from 0 to 9 with a mean of $4.7(S D \pm 1.8)$. Factors which were significantly associated with the better knowledge score was male gender, having a high educational degree, being trained in waste management and has been in service for more than 5 years. $68 \%$ of HCPs followed the color coding system, 91\% always/frequently disposed used sharps/needles to safety boxes, $79 \%$ always or frequently recapped needles, $49 \%$ reported experiencing at least one needle prick injury during their work but only $37 \%$ of them had reported the injury to a supervisor and only $4 \%$ of those injured had filled an injury form. There is a low average level of knowledge and the unsafe risky practices are quite prevalent in HCFs. Provision of appropriate training on dealing with medical waste is essential to promote safe practices among HCFs.
\end{abstract}

Keywords: Medical waste management, health staff, recapped needles, training, KAP, Iraq

\section{INTRODUCTION}

The term "medical waste" is used to describe wastes generated by health facilities such as hospitals, primary health centers, research centers and clinical laboratories [1]. Medical wastes are mixtures of municipal, pharmaceutical, laboratory, pathological, chemical, plastic and metal wastes [2]. The most dangerous aspect of the medical waste comes from the handling of waste, since waste handlers are exposed to needle prick injuries by contaminated needles and sharps, which may lead infections with Human immunodeficiency virus, hepatitis $\mathrm{B}$ and $\mathrm{C}$ viruses, and this risk is highest in health facilities amongst health care workers [3].

Medical waste is considered the second most hazardous waste globally and it is required to be treated and disposed by trained health care professionals (HCPs). Knowledge, attitude and practices of HCPs are very important while managing this type of waste. Therefore education of HCPs, staff implicated in waste collection, patients, and attendant on medical waste are very important [4]. Having proper knowledge among the HCPs about the guidelines and regulations of medical waste handling can have great impact towards the safe disposal of medical waste, and can also help to protect the community from the adverse health and environmental impact of medical waste [5]. In addition to knowledge, proper and safe attitudes and practices in dealing with medical waste during handling and disposal are crucial. Inadequate training of healthcare workers and negligence in implementation of legislations and rules will cause unsafe disposal of medical waste and could lead to serious impacts on the environment and community health [6].

HCFs are in need of continuing health education for management and support staff members in order to apply safe methods of medical waste handling and management [7-9]

The aim of this study was to assess the knowledge, attitude and practices of HCPs in HCFs of Sulaimani city (Kurdistan region, Iraq) who are involved in medical waste production and management. The study also aimed to identify factors associated with better knowledge and practices of health staff in relation to medical waste management.

\section{LITERATURE REVIEW}

One of the major key factors for proper medical waste management is the knowledge, attitude and behaviors of the health care workers in healthcare facilities in relation to medical waste [9]. Health care personnel should have a proper level of knowledge, good attitude and practices while dealing with medical waste during handling and disposal [9]. Due to inadequate training of healthcare workers and ignorance in implementation of legislations and rules, there is indiscriminate disposal of medical 
waste will have serious impacts on the environment and community health [9].

A study done in Ghaza strip - Palestine reports that private and public healthcare facilities still suffer from inappropriate management of medical waste; healthcare workers do not have information on the place of medical waste storage and methods used for management, there is a deficiency in providing training to improve their knowledge, attitude and practices and only half of those interviewed had participated in training courses about how to deal with medical waste management [10].

A study done in King Abdulla hospital in Jordan reported that despite government plans and efforts for implementation of medical waste management rules and legislations, it still does not meet the safety standards for healthcare workers inside public hospitals and outside . The study also reports that there are still many wrong practices that may lead to real problems regarding public health and environment safety [11].

In Tabriz, Iran, a study by Taghipour and Mosoferi revealed that medical wastes are poorly managed in healthcare facilities and there are no suitable health and environment safety measures available [12] it also reports that medical wastes are handled by poorly or non-educated workers without using any safety measures such as personal protective equipments [12].

A study conducted in Morocco revealed that healthcare facilities are in need of continuous training courses for old and new employees, continuing health education for management and support staff members in order to apply safe methods of medical waste handling and management [13].

A study done in Karantaka in India reported that across all participants, the knowledge regarding medical waste management was inadequate and they were unaware of medical waste management rules and regulations [9]. Another recent Indian study compared the medical waste knowledge, attitude and practices among health care personnel and showed that doctors, nurses and laboratory technicians had a better knowledge than the cleaning (sanitary) staff regarding biomedical waste management [14].

A regular training program can guarantee smooth running of medical waste managing in healthcare facilities [15].And should complementary to existing infrastructure and regulations for medical waste management. Continuous training on different aspects of handing and management of medical waste must be carried out in healthcare facilities in order to develop healthcare staff awareness regarding medical waste and its risks [15]. Medical waste handlers should be trained on segregation, handling, storage and disposal procedures [15] and should receive certificates of proficiency after successful completion of appropriate training [16]. Medical waste management supervisors and infection control officers have to provide waste handlers with personal protective equipment's such as proper gloves, masks, special shoes (puncture proof), in order to prevent needle stick injuries and various other injuries that waste handlers are exposed to [16].
All healthcare workers have to be trained in order to develop awareness before starting working in any healthcare facility [16]. Refresher training course are needed for healthcare workers in order to update and refresh the knowledge of staff dealing directly with medical wastes [16]. Training should include awareness rising about the potential hazards from waste, the purpose of immunization, safe waste-handling procedures, reporting of exposures and injuries, and the use of PPE [1]

\section{METHODS AND MATERIALS}

This was a cross sectional survey of the knowledge, attitude and behaviors of HCPs in Sulaimani city. The study locations were selected from a list provided by Directory of Health (DOH) planning section containing 9 nine public hospital, 1 one dental center, and 52 primary health centers (PHCs) and 18 private hospitals. All public hospitals and the dental center were included in the study. A total of ten from 52 PHCs and 5 from 18 private hospitals were selected by random sample selection. A self-administered questionnaire was distributed to $430 \mathrm{HCP}$ in selected health facilities. Data collection was done during March and May 2015. All HCPs working in the selected Sulaimani city health facilities having a degree such as high school, nursing school, diploma and Bachelor of Science (BSc) were eligible to take part in the study. The self-administered questionnaires consisted of 34 questions to assess the level of knowledge, attitudes, and behaviors in relation to MWM as well as socio-demographic characteristics. A database was developed in EpiData version 3.1.1 and used for data entry. All questions were pre-coded. Analysis of data was performed using Statistical Package for Social Science (SPSS) version 17.0. Individual questions were reported as frequencies and percentages and the total knowledge score was calculated by summing all knowledge questions. The mean of this score was compared for associations using t test. Chisquared test was used to assess associations between categorical variables.

The most appropriate way of identifying the categories of health-care waste is by sorting the waste into colorcoded plastic bags or containers [1].

\section{RESULTS}

The sample involved 14 public and private hospitals and 10 primary health centers randomly selected from 52 health care facilities inside Suliamani city. Out of an intended sample of 430, 406 completed questionnaires were returned mounting to a response rate of $94 \%$. 66,5 per cent of respondents were from hospitals. 
Table1. Selected HCFs and number of participants

\begin{tabular}{|c|c|}
\hline Hospitals & $\begin{array}{c}\text { Primary health } \\
\text { centers }\end{array}$ \\
\hline Shorish Teaching Hospital & Sarwary PHC \\
\hline Plastic Surgery Hospital & Ibrahim pasha $\mathrm{PHC}$ \\
\hline Shar Hospital & Shahid Rafiq hama jan PHC \\
\hline $\begin{array}{l}\text { Shahid Dr Hemin Teaching } \\
\text { Hospital }\end{array}$ & Chwarbakh PHC \\
\hline Peramerd Dental center & Shahid dr Sardar PHC \\
\hline $\begin{array}{l}\text { Sulaimani Maternity Teaching } \\
\text { Hospital }\end{array}$ & Wloba PHC \\
\hline $\begin{array}{l}\text { Sulaimani Pediatric Teaching } \\
\text { hospital }\end{array}$ & Shahid Jaza PHC \\
\hline Shahid Dr.Aso Teaching hospital & Kareza wishk PHC \\
\hline Herem Private Hospital & Faiq Haji Ali PHC \\
\hline Hiwa Teaching Hospital & Shahid Rebaz PHC \\
\hline Sulaimani Teaching Hospital & \\
\hline Roonaky Private hospital & \\
\hline Tooy malik Private hospital & \\
\hline Soma Private hospital & \\
\hline
\end{tabular}

Table2. Characteristics of participants $(n=406)$

\begin{tabular}{|l|c|c|}
\hline \multicolumn{1}{|l|}{ Gender } & $\#$ & $\%$ \\
$\quad$ Female & 261 & 64.3 \\
Male & 145 & 35.7 \\
\hline Age group & & \\
21-30 & 121 & 29.8 \\
31-40 & 135 & 33.3 \\
41 and over & 150 & 36.9 \\
\hline Qualification & & \\
Nursing school & 140 & 35.1 \\
Institute & 198 & 49.6 \\
College & 61 & 15.3 \\
\hline Working years & & \\
1-5 years & 110 & 27.1 \\
6-10 years & 64 & 15.8 \\
>10 years & 232 & 57.1 \\
\hline Training course & & \\
Yes & 82 & 20.3 \\
No & 322 & 79.7 \\
\hline Training course period & & \\
1-7 days & 55 & 67.1 \\
>7 days & & 32.9 \\
\hline
\end{tabular}

Table 3. Association of mean score with various characteristics of the participants

\begin{tabular}{|c|c|c|c|c|c|}
\hline & $\#$ & $\begin{array}{l}\text { Mean } \\
\text { score }\end{array}$ & $95 \% \mathrm{CI}$ & $\begin{array}{c}\text { Mean } \\
\text { differnce }\end{array}$ & $\begin{array}{c}P \\
\text { value }\end{array}$ \\
\hline $\begin{array}{l}\text { Overal } \\
\text { score }\end{array}$ & 406 & 4.66 & $4.27-4.71$ & - & - \\
\hline \multicolumn{6}{|l|}{ Gender } \\
\hline Male & 144 & 5 & $4.69-5.30$ & $0.5(0.12-0.87)$ & 0.01 \\
\hline Female & 261 & 4.49 & $4.27-4.72$ & & \\
\hline \multicolumn{6}{|l|}{$\begin{array}{l}\text { Service } \\
\text { years }\end{array}$} \\
\hline $0-5$ years & 110 & 4.35 & $4.05-4.65$ & $\begin{array}{c}0.70(0.16- \\
1.24)\end{array}$ & 0.01 \\
\hline $\begin{array}{l}6-10 \\
\text { years }\end{array}$ & 64 & 5.05 & $4.56-5.54$ & & \\
\hline \multicolumn{6}{|l|}{$\begin{array}{l}\text { Institute/ } \\
\text { collge } \\
\text { Degree }\end{array}$} \\
\hline No & 140 & 4.33 & $4.05-4.61$ & $\begin{array}{l}0.54(0.16- \\
0.91)\end{array}$ & 0.006 \\
\hline Yes & 259 & 4.86 & $4.63-5.1$ & & \\
\hline \multicolumn{6}{|l|}{ Training } \\
\hline Yes & 82 & 5.62 & 5.24-6.0 & $\begin{array}{c}1.22(0.79- \\
1.65)\end{array}$ & $>0.001$ \\
\hline No & 322 & 4.4 & $4.21-4.60$ & & \\
\hline \multicolumn{6}{|l|}{$\begin{array}{l}\text { Training } \\
\text { duration }\end{array}$} \\
\hline 1-7 days & 55 & 5.67 & $5.21-6.14$ & $\begin{array}{c}0.15(-0.67- \\
0.99)\end{array}$ & 0.7 \\
\hline $\begin{array}{l}\text { More } \\
\text { than } 7 \\
\text { days }\end{array}$ & 27 & 5.52 & $4.78-6.23$ & & \\
\hline
\end{tabular}

\section{Knowledge of HCPs on medical waste management}

Over $66.2 \%$ of HCPs have information on color coding system (table 3 ). Only $16 \%$ of HCPs had information on the amount of medical waste in relation to general waste in the hospital. About $40 \%$ knew how medical waste is managed in routine practice and over $28 \%$ knew who is responsible for MWM. While $96 \%$ of participants were aware that needle prick injury endangers health, only $73 \%$ had information on some specific consequences of needle prick injury.

When these knowledge questions were summed to obtain a total score, the total score ranged from 0 to 9 with a mean knowledge score of 4.7 (SD 1.8). Table 4 shows comparison of the mean score with various characteristics of participants. The mean score for people with a college/institute degree was 0.5 higher than the mean score of people with no degree and this difference was statistically significant. Other factors which were significantly associated with higher knowledge of waste management were male gender, being training and being in service for more than 5 years. 
Table 4. Knowledge of participants on medical waste management

\begin{tabular}{|l|c|}
\hline \multirow{2}{*}{ Knowledge question } & $\begin{array}{l}\text { Correct } \\
\text { answer }\end{array}$ \\
\cline { 2 - 3 } & $\begin{array}{l}\text { Number } \\
(\%)\end{array}$ \\
\hline Knows color coding of medical waste. & $259(66.2)$ \\
\hline $\begin{array}{l}\text { Knows the \% of medical waste from total } \\
\text { waste. }\end{array}$ & $62(15.9)$ \\
\hline Knows the color of municipal waste bag. & $286(71.7)$ \\
\hline Knows how medical waste is managed. & $150(38.9)$ \\
\hline $\begin{array}{l}\text { Knows who is responsible for medical waste } \\
\text { management. }\end{array}$ & $112(28.5)$ \\
\hline Knows where to put sharps and needles. & $264(66.6)$ \\
\hline $\begin{array}{l}\text { Knows where to put waste the needs } \\
\text { autoclaving. }\end{array}$ & $91(24.3)$ \\
\hline Knows needle prick injury is dangerous. & $382(96 \%)$ \\
\hline $\begin{array}{l}\text { Has information on consequences of needle } \\
\text { prick injury. }\end{array}$ & $290(73.4)$ \\
\hline
\end{tabular}

\section{Attitude of HCPs towards medical waste management}

The results of participants' opinions/attitudes on issues in relation to MWM revealed that over $96 \%$ of participants agreed with the importance of medical waste management (MWM), but $66 \%$ believed that MWM is done properly in their workplace and only $20 \%$ believed that the health facility has provided necessary training for HCP. Table 5

Table 5. Attitudes of participants in relation to medical waste management

\begin{tabular}{|l|c|}
\hline \multirow{2}{*}{ Attitude } & $\begin{array}{l}\text { Correct } \\
\text { answer }\end{array}$ \\
\cline { 2 - 3 } Number (\%) \\
\hline $\begin{array}{l}\text { Believes proper MW segregation and } \\
\text { management is important }\end{array}$ & $390(96.1)$ \\
\hline $\begin{array}{l}\text { Believes MW segregation and } \\
\text { management is a team work }\end{array}$ & $330(82.1)$ \\
\hline $\begin{array}{l}\text { Believes MW segregation management } \\
\text { is a burden on HCP }\end{array}$ & $91(22.4)$ \\
\hline $\begin{array}{l}\text { Believes MWM is properly done in } \\
\text { his/her workplace }\end{array}$ & $265(66.4)$ \\
\hline $\begin{array}{l}\text { Believes workplace has opened } \\
\text { necessary courses on MWM }\end{array}$ & $79(19.9)$ \\
\hline $\begin{array}{l}\text { Feels ready to participate in training on } \\
\text { MW management }\end{array}$ & $287(71.4)$ \\
\hline $\begin{array}{l}\text { Believes all health facilities must have a } \\
\text { system for cleaning sewerage }\end{array}$ & $380(96.0)$ \\
\hline $\begin{array}{l}\text { Believes health authorities must be } \\
\text { informed on breaches in relation to } \\
\text { MWM }\end{array}$ & $378(95.9)$ \\
\hline
\end{tabular}

\section{Practices of HCPs in relation to medical waste}

The study showed that $68 \%$ of HCPs followed the color coding system for segregation of medical waste. While $91 \%$ of HCPs always/frequently disposed of used sharps and syringes to safety boxes, $9 \%$ of HCPs never or only sometimes did so. Recapping the used needles was a common practice in $79 \%$ of HCPs who always or frequently did so while only $12 \%$ reported they never recapped used needles. In this relation $49 \%$ of participants reported that they had experienced at least one needle prick injury during their work but only $37 \%$ of them had reported the injury to a supervisor and only $4 \%$ of those injured had filled an injury form. Table 6

Table 6. Practices of participants in relation to medical waste management

\begin{tabular}{|c|c|}
\hline Practice & $\begin{array}{l}\text { Correct } \\
\text { answer } \\
\text { Number } \\
(\%)\end{array}$ \\
\hline \multicolumn{2}{|l|}{$\begin{array}{l}\text { Disposes of needles and sharps to safety } \\
\text { box. }\end{array}$} \\
\hline Never & $10(2.5)$ \\
\hline Sometimes & $26(6.6)$ \\
\hline Frequently/always & $359(90.9)$ \\
\hline \multicolumn{2}{|l|}{ Recaps needles after use. } \\
\hline Never & 47 (11.9) \\
\hline Sometimes & $35(8.9)$ \\
\hline Frequently/always & $213(79.2)$ \\
\hline $\begin{array}{l}\text { Performs segregation of } \mathrm{MW} \text { according } \\
\text { to color coding system. }\end{array}$ & $268(67.5)$ \\
\hline \multicolumn{2}{|l|}{$\begin{array}{llll}\begin{array}{l}\text { Experienced } \\
\text { needle/sharps. }\end{array} & \text { injury } & \text { by } & \text { used } \\
\end{array}$} \\
\hline Never & $204(51.0)$ \\
\hline Once/few times & $156(39.0)$ \\
\hline Many times & $40(10.0)$ \\
\hline \multicolumn{2}{|l|}{$\begin{array}{l}\text { When injured by needle/sharps, } \\
\text { informed person in charge. }\end{array}$} \\
\hline Yes & $70(36.7)$ \\
\hline No & $100(52.3)$ \\
\hline Don't remember & $21(11.0)$ \\
\hline $\begin{array}{l}\text { When injured by needle/sharps, filled } \\
\text { accident form }\end{array}$ & $8(4.2)$ \\
\hline
\end{tabular}

\section{DISCUSSION}

The present study was conducted in different selected public and private HCFs which are under authority of $\mathrm{DOH}$ in Sulaimani. The study assessed level of 
knowledge, attitude, and practices of HCPs regarding MWM. The knowledge, attitude and practices of HCPs were dissimilar among participants; many factors may lead to this difference like the level of education of HCPs, working experience, participation in training courses and their practical involvement in the hospital waste handling and MWM.

This study showed that gender, service years, qualification and participation in training were statistically significant factors of better knowledge while duration of training course was not.

The current study showed that from a total of 406 HCPs participated in the study, 261(64.3\%) were females and $145(35.7 \%)$ were males with female to male ratio of $1: 1.8$. The present study showed that $66 \%$ of HCPs have information on color coding system; this was similar to a study done in Pondicherry- India reported that $50 \%$ of HCPs had the knowledge of color coding and segregation of MWM [17], this result was also comparable to a study done in Pakistan reporting that $86 \%$ HCPs have information about waste color codes [18]. Another similar study from West Bengal revealed that $76 \%$ HCPs knew about various types of colorcoding bags for collection of MW [19]. In the present study $15.9 \%$ of HCPs have knowledge about the percentage of MW in whole waste. This was similar to a study done in Delhi, India reporting that HCPs with knowledge of approximate proportion of infectious waste generated in HCFs were found to be $36 \%$ [20]. Another study from India reported that HCPs knowledge about the proportion of infectious waste generated from a hospital was found only in $39.3 \%$ of respondents [21]. This may be due to low level of HCPs knowledge and the absence of national guidelines in HCFs.

The current study showed that gender, participation in training, qualification, and service years were significantly associated with better knowledge of waste management while training duration was not. Regarding training course in relation to MWM (79.7\%) of HCPs had not participated in any training courses during their working periods and only (20.3\%) HCPs have participated in MWM training course. This result was similar to a study done in India revealed that around $16 \%$ HCPs had received training on MWM [22] another study in Puducherry-India reported that (74\%) of HCPs have not undergone training on medical waste management [17]. This result was inconsistent with a study done in Turkey that reported that training of staff on medical waste was about $80 \%$ [23]. Also another study revealed that majority $(87 \%)$ of HCPs had undergone training program on medical waste management [24]. The low participation in training highlights the need for strengthening training courses and involving all HCP in such trainings. This study also shows the need for such training programs to be conducted regularly and make it compulsory for all the HCPs to attend either annually or at the beginning of their service. In the present study $96 \%$ of HCPs knows that needle prick injury is dangerous. It is similar to a study done in Bosnia and Herzegovina reported that $70 \%$ of HCPs were aware that needle prick injury carries risk for blood borne infection [25]. In the current study $96 \%$ of HCPs believe that proper management of MW is important, $82 \%$ believes that MW management is a team work, it is similar to a study done in Lucknow -India which revealed that majority of HCPs has seen MWM process as a team work and all were responsible for safe disposal [17]. This is not consistent with a study done in India which revealed that $82 \%$ has seen that safe management of healthcare waste was the responsibility of the institution and not the HCPs [26]. This difference may be due to education level, knowledge, and attitude of participants. In the present study $22 \%$ of HCPs believe that MWM is a burden on HCPs. This result was inconsistent with a study done in India revealed that attitude and practices towards BMW management majority $90 \%$ has seen that safe management of health care waste was an extra burden on work, however, $85 \%$ felt that safe management of BMW was not an issue at all [26]. In the current study $66 \%$ of HCPs believes that MWM is properly done in the workplaces and $54 \%$ of HCPs were satisfied about MWM process in their workplace. This result was similar to a study done in India reporting that $36 \% \mathrm{HCPs}$ were satisfied about waste disposal practiced in their hospital [20].

In the present study $71 \%$ of HCPs were ready to participate in voluntary training courses regarding MWM, and this rate is comparable to a study in India (96\%) where HCPs would like to attend a training program on BMW management [27]. Another study in Dilhi-India revealed that $56 \%$ of all HCPs would like to attend voluntarily programs to upgrade their knowledge on BMW [17]. However, a study from East Anglia, UK revealed that $22 \% \mathrm{HCPs}$ don't mind to voluntary attend the training sessions [28]. The present study showed that $96 \%$ of HCPs believes all health facilities must have a system for cleaning sewerage, $95 \%$ of HCPs believes health authorities must be informed on breaches in relation to MWM, 95\% HCPs thought that it is important issue to report to $\mathrm{DOH}$ if their workplace is not complying with standard MWM guidelines. This proportion is over what is reported by a study from Delhi, India which reported that $52 \%$ HCPs expressed their willingness on reporting to health authority of India about the institutions who is not complying the guidelines for MW management [17].

Regarding practices of HCPs, $91 \%$ disposes of needles and sharps to safety box frequently/always. This result was better than 53\% reported from Ethiopia [29]. This may due to that $\mathrm{DOH}$ have provided all HCFs with adequate number of safety boxes to ensure the safe disposal of needles and sharps. The present study showed that $79 \%$ of HCPs recap needles after use either frequently or always which is a risky practice exposing the person to needle prick injury. This is similar to a study done in Puducherry, India reported that nearly $50 \%$ of HCPs recap the needle [17]. It is also consistent with a study done in Nagara, India reporting that practice of recapping the needles was observed to be $67 \%$ among all the categories of HCPs [27]. This result was different from a study done in Ethiopia showed that $(73 \%)$ do not practice recapping needles after injection [29]. In Lebanon, a study revealed that $67 \%$ HCPs were aware that needles should not be recapped after use [30]. In a study done in India, the practice of recapping of used 
needles was done by $25 \%$ [24]. In the current study the practice of recapping the used needles may be due to lack of awareness and continuation of an old habit, difference in academic background of HCPS and lack of adequate number of needle cutters in the HCFs. This risky practice could be managed by providing all HCFs with needle cutters with enforcement rules for safe disposal of used needles and sharps in HCFs.

In relation to experiencing injuries, in the current study $49 \%$ of HCPs experienced injury by used needle/sharps either once or multiple times during their working time, which was consistent with a study from India reporting that 55\% HCPs had experienced needle prick injuries in their work life [31]. Another study done in Cairo revealed that $46 \%$ of HCPs had needle prick injury or sharp injury and $19 \%$ of health care worker had sharp or needle prick injury within the last year [32]. Another study identified that $51 \%$ HCPs were subject to injuries caused by a sharp tool in a 6-month period and that $80 \%$ of those injuries were inflicted by injectors [33]. In a study from Karnataka, India experiencing of needle prick injury was less than the present study and only $21 \%$ of medical staff reported needle prick injuries [34]. This difference may due to lack of occupational health and safety section and guidelines in the HCFs. This risk could be minimized or avoided by opening regular training courses, and enforcement of all HCPs to enroll in these courses. The present study showed that $52 \%$ of HCPs when injured by needle/sharps did not report even verbally persons in charge which is not a safe practice and is in contrast to the study in which only $19.9 \%$ of the needle pricks injured respondents did not report to the hospital authority [35]. Another study from India reported that $55 \%$ of HCPs had reported the incident to the higher authority [21]. It is important to issue clear guidelines and procedures to HCFs and HCPs to report any such injuries to the authorities and provide required treatment and support needed.

\section{CONCLUSION}

It is clear from this study that there is low level of knowledge about MWM and there are prevalent unsafe practices among HCPs in relation to waste management and occupational safety. There is need for training and awareness programs about different components of medical waste management and occupational safety for HCPs for waste collectors and cleaners who are engaged directly in the process of handling, collecting and disposing medical waste. Clear MWM guidelines have to be adopted and enforced in HCFs to reduce risks on patients, HCPs, and the community. Guidelines and procedures should be put into place to record and report any breaches in relation to MWM and any occupational risks affecting HCPs.

\section{REFERENCE}

[1] A. Prüss, E. Giroult, P. Rushbrook, "Safe management of wastes from health-care activities," World Health Organization, 2014.

[2] World Health Organization, Joint FAO/NACA/WHO, "Study Group on Food Safety
Issues report of a joint FAO/NACA/WHO study group," World Health Organization, 1999.

[3] SA. Tabish, "Hospital Infection Control: Conceptual Framework," Academa Publishers," Ecohealth: Management of Biomedical Waste, pp. 139-145, 2005.

[4] YW. Cheng, FC. Sung, YC. Yang, YH. Lo, YT. Chung and $\mathrm{KC}$. Li, "Medical waste production at hospitals and associated factors," Journal of Waste Management, vol. 29, pp. 440-444, 2009.

[5] P Stanley, "The Earth Summit: The United Nations Conference on Environment and Development (UNCED)," London: Graham \& Trotman, 1993.

[6] A. Pruss, E. Giroult and P. Rushbrook, "Safe management of waste from health activities," Geneva: World Health Organization, 1999.

[7] E. Weir, "Hospital and the environment. Journal of Canadian Medical Association," vol. 166, pp. 354369, 2002.

[8] FJ. Aukour, "Healthcare Waste Management in Jordan King Abdullah University Hospital case study,” J. Sci. Med Eng, vol. 20(1), pp. 61-77, 2008.

9] M. Marki, A. Dnane, "Medical Waste Management: A Case Study of the Souss-Massa-Drâa Region, Morocco," 2013.

[10] M. Marki, A. Dnane, "Medical Waste Management: A Case Study of the Souss-Massa-Drâa Region, Morocco," 2013.

[11] L. Muhwezi, P. Kaweesa, F. Kiberu, \& I. Eyoku, "Health Care Waste Management in Uganda-A Case Study of Soroti Regional Referral Hospital," International Journal of Waste Management and Technology, vol. 2, pp. 1 - 12, 2014.

[12] M. Azage, A. Kumie, "Healthcare waste generation and its management system: the case of health centers in West Gojjam Zone, Amhara Region, Ethiopia," Ethiopian Journal of Health Development, vol. 24(2), 2010.

[13] S. Rasheed, S. Iqbal, LA. Baig, K. Mufti, "Hospital Waste Management in theTeaching Hospitals of Karachi,”JPMA, vol. 55, pp.192, 2005.

[14] F. Abdulla, HA. Qdais, A. Rabi, "Site investigation on medical waste management practices in northern Jordan," Waste management, vol. 31, pp. 450-8, 2008.

[15] A. Sarsour, A. Ayoub, I. Lubbad, A. Omran, I. Shahrour, "Assessment of Medical Waste Management within Selected Hospitals in Gaza Strip Palestine: A Pilot Study," International Journal of Scientific Research in Environmental Sciences, vol. 1, pp. 164, 2014.

[16] F. Malekahmadi, M. Yunesian, "Analysis of the healthcare waste management status in Tehran hospitals," Journal of Environmental Health Science and Engineering, vol. 27, pp. 1, 2014. 
[17] M. Azage, G. Haimanot, and M. Mesafint, "Healthcare waste management practices among healthcare workers in healthcare facilities of Gondar town," Northwest Ethiopi, vol. 7, pp. 315-322, 2013.

[18] A. Malini, B. Eshwar, "Knowledge, Attitude and Practice of Biomedical waste management among health care personnel in a tertiary care hospital in Puducherry," International Journal of Biomedical Research, vol. 30, pp. 172-6, 2015.

[19] R. Kumar, A. Zulfiqar, AG. Zulfikar, “Assessment of health care waste management practices and knowledge among HCPs working at tertiary care setting of Pakistan, J Health Res, vol. 27, pp. 4, 2013.

[20] M. Basu, P. Das, R. Pal, “Assessment of future physicians on biomedical waste management in a tertiary care hospital of West Bengal," Journal of natural science, biology, and medicine. Vol. 3, pp. $38,2012$.

[21] S. Pradhan, S. Prasad, BR. Chinmaya, S. Tandon, "Perception of Biomedical Waste Management among Dental Health Care Personnel of Various Dental Colleges in Delhi NCR, India: A Knowledge, Attitude, and Practice Study, ijss, vol. 10, pp. 208, 2016.

[22] U. krishnan, T. Shiela, D. Devamani, "Where Lies the Grey Zone in Implementation of Biomedical Waste Management? A KAP Study," NJLM, vol. 12, pp. 204, 2015.

[23] R. Sanjeev, S. Kuruvilla, R. Subramaniam, PS. Prashant, M. Gopalakrishnan, "Knowledge, attitude, and practices about biomedical waste management among dental healthcare personnel in dental colleges in Kothamangalam: a cross-sectional study," Health Sciences, vol. 1, pp. 1-2, 2014.

[24] M. Akbolat, DE. Cemile, IS. Oguz, H. Saglam, "Medical waste management practices in Turkey: A case study in Sakarya," Pak J Med Sci, Vol. 27, 892- 895. 2011.

[25] RK. Sehgal, R. Garg, PS. Dhot, P. Singhal, "A study of knowledge, attitude, and practices regarding biomedical waste management among the health-care workers in a multispeciality teaching hospital at Delhi," International Journal, vol. 4, pp. 1540, 2015.

[26] S. Jankovic, J. Bojanic, A. Jovic-Vranes, J. Marinkovic, J. Jankovic, "Knowledge, attitudes and practices towards blood-borne pathogens in HCPs in Banja Luka, Bosnia and Herzegovina," Central European journal of medicine, vol. 4, pp. 409-14, 2009.

[27] A. Khanna, "An Assessment of Knowledge, Attitude and Practices about Biomedical Waste
Management among Owners of Nursing Homes/Private Hospitals in the Central Area of Uttar Pradesh, India, International Journal of Health Sciences and Research (IJHSR), vol. 4, pp. 10-6, 2014.

[28] R. Radha, "Assessment of existing knowledge, attitude, and practices regarding biomedical waste management among the HCPs in a tertiary care rural hospital," International Journal of Health Services and Research, pp. 14-19, 2012.

[29] KP. Pudussery, "Study On the Medical Waste Management in the Norfolk AND Norwich University Hospital (Doctoral dissertation, MS Thesis,' University of East Anglia, School of Environmental Sciences), 2012.

[30] MS. Mulatu, P. Converse, M. Kaba, DH. Mariam, W. Mekonnen, H. Kloos, "Bibliography on HIV/AIDS in Ethiopia and Ethiopians in the Diaspora: The 2013 Update," Ethiopian Journal of Health Development, vol. 28, pp. 45-72, 2014.

[31] I. Sabbah, H. Sabbah, S. Sabbah, H. Akoum, N. Droubi, "Occupational exposures to blood and body fluids (BBF): Assessment of knowledge, attitude and practice among HCPs in general hospitals in Lebanon, Health, vol. 5, pp. 70, 2013.

[32] M. Asadullah, GK. Karthik, B. Dharmappa, "A Study on Knowledge, Attitude and Practices Regarding Biomedical Waste Management Among Nursing Staff in Private Hospitals in Udupi City," Int J Geol Earth Environ Sci, vol. 3, pp. 118-23, 2013.

[33] SA. Hakim, A. Mohsen, I. Bakr, "Knowledge, attitudes and practices of health-care personnel towards waste disposal management at Ain Shams University Hospitals, Cairo," EMHJ, vol. 20, pp. 5, 2014.

[34] H. Fiedler, "National PCDD/PCDF release inventories under the Stockholm convention on persistent organic pollutants," Chemosphere, vol. 67, pp. 96-108, 2007.

[35] V. Ferreira, M. Ribau, "Assessing the medical waste management practices and associated risk perceptions in Algarve hospitals, Portugal," InISWA/APESB world congress, 2009.

[36] C. Ketlogetswe, MT. Oladirang and J. Foster, "Improved combustion process in medical waste incinerators for rural application," African Journal of Science and Technology, vol. 5, pp. 67-72, 2004.

\section{ACKNOWLEDGMENTS}

I would also like to thank Technical College of health research and the scientific committee for their support, grateful thanks to Sulaimani Directorate of Health for their support.

\section{Biography}

\section{Corresponding author}

SarkoMasood Mohammed, BSc, MSc 
Technical College of Heath, Sulaimani Polytechnic University

Sulaimani, Iraq

Email:sarko.mohammed@spu.edu.iq

Mobile: +9647702423636 